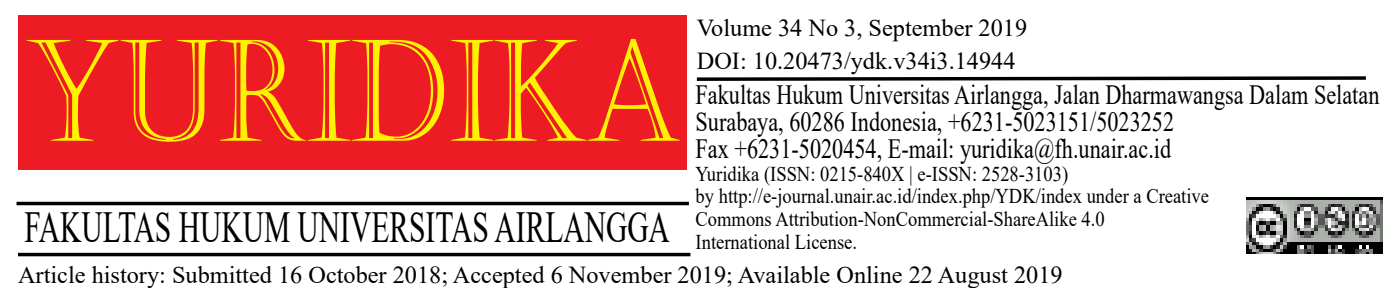

\title{
Cotton Plantations in India: the Environmental and Social Challenges
}

\author{
Arun Sahay \\ arun.sahay@bimtech.ac.in \\ Birla Institute of Management Technology
}

\begin{abstract}
Cotton, one of the principal cash crops of India, contributes significantly to the country's economy and foreign exchange earnings. Approximately 60 million people depend on cotton production and related industries for their livelihoods. Although India has the largest cotton plantation area, in terms of yield, it is far behind. Even though cotton occupies only five percent of India's total cultivable land, approximately 50 percent of pesticides used in India are consumed by the cotton cultivation, causing environmental pollution and health hazard. The use of nitrogen-based fertilizers further increases the problem. Many social issues such as child labor, women labor, extremely small landholdings and unviable livelihoods are associated with cotton plantations. Recently, due to the norms set up by the textile importing countries, these issues have assumed great importance. This article, after giving a brief introduction to the cotton plantation sector in India, will deal with the environmental and social challenges of the cotton plantations.
\end{abstract}

Keywords: Cotton; Fertizilers; Plantation.

\section{Introduction}

The word "cotton" is derived from the Arabic word "al-qutun," which in turn seems to have roots in the Sanskrit word "kapas." Arabs used to buy cotton from India and trade it with Europe. Among worldwide agriculture, the importance of cotton is very high, as it occupies a cultivated area of 2.3 percent of the total arable land of the globe, and can grow in completely different socio-economic, environmental, and climatic conditions. Though cotton plantations are widely scattered, i.e., 75 countries worldwide account for the major output, developing countries have the 
highest concentration of cotton farming. ${ }^{1}$ The cotton production is dominated by India and China, each with about 25 percent of the global share. The cotton production is central to economic growth for many developing countries. Not only does the cotton cultivation generate income for millions of farmers, but it is also a source of livelihood for millions more engaged in the entire textile value chain. In addition to contributing greatly to the gross domestic product, it also facilitates foreign exchange earnings.

As per the International Cotton Advisory Committee (2012), cotton plantations can be found in over 100 countries. The productivity of cotton in terms of yield per hectare varies widely among these countries. Australia is the most productive (Bremen Cotton Exchange, 2014). The USA, despite a high degree of mechanization, does not rank in the high yielding countries (Figure 1). India is a distant $36^{\text {th }}$ in terms of yield. However, the last three years saw an increase in productivity in India, made possible by the large-scale commercial cultivation of wide yielding hybrid varieties in long and extra-long staples. Even though the Indian yield increased threefold over that period, the outcome of $504 \mathrm{~kg} / \mathrm{ha}$ is still way behind the yield of $1,008 \mathrm{~kg} / \mathrm{ha}$ of the USA and the $1,761 \mathrm{~kg} / \mathrm{ha}$ of China, not to speak of the Australian yield of 2,202 kg/ha. See Figure 1 (Index Mundi, 2018).

Figure 1. Cotton Yield per Country ${ }^{2}$

\begin{tabular}{|c|c|c|}
\hline \multicolumn{2}{|c|}{ Rank Country } & \multirow{2}{*}{$\frac{\text { Yield (KG/HA) }}{2,202.00}$} \\
\hline 1 & Australia & \\
\hline 2 & Turkey & $1,853.00$ \\
\hline 3 & China & $1,761.00$ \\
\hline 4 & Israel & $1,742.00$ \\
\hline 5 & Mexico & $1,597.00$ \\
\hline
\end{tabular}

1 Textile Fashion Study, 'Cotton Cultivation: Top Cotton Producing Countries of the World' (Textile Fashion Study, 2013) <http://textilefashionstudy.com/cotton-cultivation-top-cotton-producing-countries-of-the-world/> accessed 26 March 2018.

2 United States Department of Agriculture, 'Cotton Yield By Country in KG/HA' (United States Department of Agriculture, 2019) <https:/www.indexmundi.com/agriculture/?commodity $=$ cotton $\&$ graph $=$ yield $>$ accessed 26 March 2018 . 


\begin{tabular}{llr}
6 & Brazil & $1,555.00$ \\
7 & Venezuela & $1,234.00$ \\
8 & Bulgaria & $1,089.00$ \\
9 & Colombia & $1,089.00$ \\
10 & Tunisia & $1,089.00$ \\
\hline
\end{tabular}

Among the cotton-producing countries, China, India, and the USA are the top rankers (Table 1). The production systems for cotton growing vary worldwide. The USA has large mechanised systems that are capital intensive but very low on labor input. Developing and less developed countries cultivate cotton in small family farms, where it is handpicked. In Africa, for example, where six percent of all global cotton is produced, plantations dominated by smallholders support the livelihoods of approximately 20 million people. In India cotton plantations are in mixed mode, consisting of both small family farms as well as commercial cultivations.

Table 1. Top Cotton Producing Countries in the World ${ }^{3}$

\begin{tabular}{llc}
\hline Rank & Country & Cotton Production in Thousand Metric Tonnes \\
\hline 1 & China & 6,532 \\
\hline 2 & India & 6,423 \\
\hline 3 & United States & 3,553 \\
\hline 4 & Pakistan & 2,308 \\
\hline 5 & Brazil & 1,524 \\
\hline 6 & Uzbekistan & 849 \\
\hline 7 & Turkey & 697 \\
\hline 8 & Australia & 501 \\
\hline 9 & Turkmenistan & 332 \\
\hline 10 & Mexico & 297 \\
\hline
\end{tabular}

\footnotetext{
3 Khushboo Sheth, 'Top Cotton Producing Countries in The World' (Worldatlas, 2017) $<$ https://www.worldatlas.com/articles/top-cotton-producing-countries-in-the-world.html $>$ accessed 23 March 2018.
} 


\section{Cotton Plantations in India}

Cotton plantations in India started in the Indus valley civilization (33001300BC) when cotton threads were extracted from the produce. Harappans were the first people to grow cotton for clothing, sheets, and towels. Since cotton has become an important part of the Indian economy. Beyond its economic value, it has also played social and moral roles. In the ancient days, only ideogram arboretum and herbaceum varieties of cotton were grown in different regions of the country. These types of cotton have a staple length of $25 \mathrm{~mm} .{ }^{4}$ The cultivation of these varieties continued until the middle of the $19^{\text {th }}$ century. The American Civil War (1861-1865) throttled the supply of cotton to England. In 1904 to 1905 the East India Company introduced American cotton to India, a variety that proved promising with the proper irrigation. Until the beginning of World War I in 1914, India produced four to five million bales of cotton per year, and almost all of them were 'desi' (local) cotton with a short staple length (below 19mm). This limitation was the reason for India, a major cotton exporter, to import higher quality cotton.

In India, genetically modified (GM) cotton was introduced in 2002 (Qaim et al., 2006) when the first 'three Bt cotton hybrids' were commercially approved. Mahyco, an Indian company, in collaboration with Monsanto, developed these hybrids. In 2004, Rasi Seeds developed and commercialized the 'fourth Bt hybrid'. In the growing season of 2007 to 2008, a total of 131 different 'Bt hybrids' were grown in India (James, 2007). Bt cotton has steadily prevailed over India's cotton fields ever since, resulting in a cotton sowing area growing from about 87.86 lakh hectares in 2004 to 2005, to 119 lakh hectares in 2008 to 2009. This change in cultivation pattern marked a difference in productivity: yields increased from two to five quintals per hectare in the pre-Bt era to six to twelve quintals per hectare afterward. One of the reasons for this increase is that the GM crop is bollworms resistant. Today, over 4 million cotton farmers in India use approximately 19 million hectares of land for cotton cultivation, the largest surface in the world.

4 International Trade Centre, 'Cotton Exporter's Guide' (cottonguide, 2018) <http://www. cottonguide.org/cotton-guide/market-segments-types-of-cotton/> accessed 23 March 2018. 
Hybrids account for about 50 percent of the cotton area and 60 percent of the production in India.

In the financial year of 2016 to 2017, the cotton production increased again from 33.80 million bales to 35.10 million bales (See table 2). During that same year, both the cotton export and import fell from 6.9 to 5.0 million bales and 2.0 to 1.7 million bales, respectively (Cotton Advisory Board, 2016).

Table 2. ${ }^{5}$ Quantity in a million bales of $170 \mathrm{~kg}$

\begin{tabular}{|c|c|c|}
\hline Item & 2016-2017 & 2015-2016 \\
\hline \multicolumn{3}{|c|}{ Supply } \\
\hline Opening Stock & 4.30 & 6.60 \\
\hline Crop Size & 35.10 & 33.80 \\
\hline Imports & 1.70 & 2.00 \\
\hline Total Availability & 41.10 & 42.40 \\
\hline \multicolumn{3}{|c|}{ Demand Supply } \\
\hline Mill Consumption & 27.50 & 27.20 \\
\hline Small Mill Consumption & 2.80 & 2.70 \\
\hline Non-Textile Consumption & 1.00 & 1.30 \\
\hline Total Consumption & 31.30 & 31.20 \\
\hline Export & 5.00 & 6.90 \\
\hline Total Disappearance & 36.30 & 38.10 \\
\hline Carry Forward & 4.80 & 4.30 \\
\hline
\end{tabular}

As far as India is concerned, cotton still occupies a prime position within the textile industry, despite synthetic human-made fiber making inroads. Cotton has been in cultivation for over 5000 years and continues to be a traditional and important commercial cash crop. However, the cultivation of cotton poses more problems than other agricultural commodities. It is very dependent on the fertility of the soil, climatic situations, wide yielding varieties of seeds and rainfall. For this reason, Indian farmers are facing many problems in the cultivation of cotton, even today.

The major cotton-producing states in India are depicted in Annexure-I. Maharashtra, Gujarat, Karnataka, Madhya Pradesh, Punjab, Rajasthan, Andhra Pradesh, Haryana, and Tamilnadu are the leading cotton-producing states. Furthermore,

\footnotetext{
5 Cotton Advisory Board (P)*Provisional, 'CCI-An Organisation' (cotcorp.org.in, 2018) $<$ https://cotcorp.org.in/Writereaddata/Downloads/FINAL CCI- An Organization.pdf $>$ accessed 23 March 2018.
} 
farmers seem to be switching to cotton growing, instead of sugarcane, pulses, etc., because of the comparatively higher prices. In India, the contribution of cotton to the total production in 2014 to 2015 was estimated at 40 percent, it is expected to grow to 55 percent (Mohansundaram, 2015) in the next cropping season.

\section{Problems Faced by Cotton Planters}

Cotton planters in India are facing many problems; the most important ones are enumerated below:

\section{Cost of Production}

The 'Minimum Support Price' offered to cotton farmers is far below the one required to optimally cover the ever-rising input costs. Although GM companies provide better technology, they sell expensive cottonseeds and fertilizers. For this reason, the farmers have to spend more leading to higher debts; in some cases, these unmanageable debts have even led farmers to commit suicide.

\section{Decreasing Yield}

Though the average yield increased from 2015 to 2017, it is now stagnating because the use of fertilizers and pesticide is increasing. This causes deterioration of the quality and the productivity of the soil. Furthermore, not only are the pests becoming increasingly resistant to chemical dosage, but new pests have also started to appear.

\section{Poor irrigation facilities}

More than 35 percent of the areas under cotton cultivation are rain-fed and have poor irrigation facilities. Thus, plantations are exposed to monsoon fluctuations, which are aggravating, year after year, due to climate change. Most of the farmers are unable to manage water resources effectively, a problem that is increasing with the depleting groundwater resources.

\section{Inferior technology}

Absence of modern technology in cultivation, as well as ginning, has affected the yield. Not only is the yield low, but if not taken proper care of, there is the risk of the cotton getting contaminated in the harvesting, marketing, and ginning stages. 


\section{Genetic purity erosion}

Due to deterioration in the genetic purity of cotton varieties and hybrid seeds and inconsistencies in the admixtures of the cotton fiber, it becomes difficult to assess the quality of the cotton production. Nonetheless, importers focus heavily on quality consistency. Further, competition from artificial fibers with a lower cost of production and higher consistency has sprung up.

\section{Unpredictable market prices}

Fluctuating market prices for cotton and the inability to compete with the low prices on the global market, enabled by the important subsidies given to cotton farmers in Western countries, are affecting cotton planters adversely. Furthermore, it has proven difficult to develop a globally competitive cotton industry in India because of the average low quality of cotton that is being produced.

\section{Non-mechanisation}

Although mechanised picking has proved better than handpicking, since the latter can lead to contamination, cotton picking is still completely manual in India. Few cotton varieties produced are amenable to mechanised plucking. Further, mechanized picking requires defoliation of the plant, but no appropriate defoliant is available in India. Meanwhile, the cost of picking cotton from the farm is increasing day by day.

\section{Non-procurement}

The Cotton Corporation of India acts as the government agency for the implementation of the Minimum Support Price operations, to help farmers to prevent distress sales and ensure a remunerative price and price stabilization. However, this corporation is not discharging its procurement duty, as such pushing cotton growers to distress.

\section{Challenges}

Cotton production and utilization, which are the two major economic activities, have major environmental and social impacts. The lives of approximately 60 million people, who are directly or indirectly connected with cotton cultivation 
and related industries in India, are influenced by environmental and social issues. The next part will elaborate on several of these key environmental and social issues.

\section{Environmental}

Worldwide, the cotton plantation process involves the intensive use of pesticides. These chemicals endanger human health in general and especially that of the cotton farmers in India. A wide range of environmental, economic, and social problems are faced by them; including soil degeneration, pollution of the environment, groundwater contamination, destruction of beneficial insects, escalation of cultivation cost, presence of pesticide residues in cotton and valueadded products, and the development of insecticide resistance and the consequent surge of pest intensity.

The major enemies faced by cotton crops in India are bollworms and sucking pests. To counter these pests, heavy doses of pesticides are used. Over 50 percent of the pesticides used in Indian agriculture is intended for cotton farming, even though cotton only occupies five percent of the cultivated land. These pesticides create a variety of environmental problems, including soil, atmospheric, and water pollution. Pesticide residues in cotton create a health hazard across and along the textile value chain. A study in India (Mancini et al. (2005)) on the effect of pesticides on farmers revealed that there were 323 hazardous events, of which 207 ( 84 percent) were associated with symptoms of mild to severe pesticide poisoning, and 32 (10 percent) were associated with symptoms typical of poisoning by organophosphates (used in 47 percent of the pesticide applications).

The EU and the USA have stipulated environmental norms for cotton import, regulating and restricting the use of certain types of pesticides. To meet such norms, the Indian government has banned the use of 25 pesticides and six formulations. Further, location-specific "Integrated Pest Management" packages have been developed, which are being promoted by the government through several instruments. One of these instruments is the "Technology Mission on Cotton", under which various 'mini- 
missions' were launched. ${ }^{6}$ Mini Mission - II about pest management was launched in 2000. Mini Mission III and Mini Mission IV (2005-2006), respectively about the modernization of ginning and pressing factories and the upgrading of market yards, was launched later. Through these missions, NGOs, such as CITI CDRA, ${ }^{7}$ and cooperatives were included in the implementation of these Mini Missions. Furthermore, the Cotton Development and Research Association got involved in the implementation of "The Front Line Demonstration Programme" on Cotton Production and Pest Management, which has as goal to enlighten farmers on crop protection through IPM.

One other instrument introduced by the government is the "All India Coordinated Cotton Improvement Project" (AICCIP) of the Indian Council of Agriculture Research (ICAR). To demonstrate new farming technologies, including IPM, AICCIP conducts over 1000 Front Line Demonstration programs. The following organizations participate in these programs:

1. ICAR Institutes;

2. State Agricultural Universities;

3. Krishi Vigyan Kendras (Agriculture Science Centers);

4. State Departments of Agriculture;

5. The Cotton Corporation of India Ltd.;

6. Several NGOs.

Thanks to this research and knowledge dissemination, the pesticide use in the cotton plantation are now diminishing. Further, the Central Institute for Cotton Research, based in Nagpur, has researched alternative bio-agents and bio-pesticides. The 'a hirsutum variety LRA-5166' demonstrated the relative merits of organic farming vis-à-vis agro-chemical farming. Though the organic farm initially produces lower yields than the nonorganic, the research reveals that in successive years, the soil of organic farms gets richer in carbon and phosphorus.

Another concern in the cotton plantation is the use of fertilisers. In the beginning, a large amount of energy is needed for the production of fertilisers,

6 Director and Member Secretary (TMC-MM-I) Central Institute for Cotton Research, 'Mission to Generate Technologies for Sustainable Cotton Production' (Technology Mission on Cotton,

$2017)<$ http://www.tmc.cicr.org.in/> accessed 27 March 2018 .
7 CITI, 'CITI CDRA' (Citi India, 2017) < https://www.citiindia.com/citi-cdra/> accessed 27 March 2018. 
which results in the release of a huge volume of carbon dioxide into the air causing global warming and climate change. In addition to this, a large quantity of nitrogen oxide (NOX) is produced through the application of nitrates to agricultural land. NOX, produced in the cotton farms, is a greenhouse gas with a potential 300 times higher than carbon dioxide to increase global warming.

Another cause of concern is that the cotton processing plants and the ports from where the cotton is exported are located in far-flung areas from the farms. This calls for long hauls of cotton, and the transportation of cotton causes atmospheric pollution and health hazard.

\section{Social}

In India, the farming of cotton calls for adherence to the Minimum Wage Act 1948, the Plantation Labour Act 1951, the Bonded Labour System Act 1976, the Protection of Human Rights Act 1993, the Equal Remuneration Act 1976, the Child Labour Act 1986 (amended in 1999), and the Unorganised Labour and the Agricultural Workers (Welfare) Act, 2006. Also, the occupational health and safety of farmers are taken care of through the Plantation Labour Act, 1951, the Insecticide Act, 1968, and the Environmental Pollution Act, 1966.

Growing cotton provides work, and work provides vital income for farmers. Cotton growing does not only impact the farmer; it also influences society around the cultivation, the state, and the nation. These social impacts can be either positive or negative. The positive impacts of cotton production are the creation of jobs, the support of livelihoods, and the contribution to the economic growth of the nation. In India, the 'social performance' of cotton plantations is described in terms of its role in creating jobs that result in income. This social performance, however, is in tension with the 'economic performance' that results from technological advances through mechanisation and transgenic seeds that cut the requirement for manual labor. Presently, there are two main forms of employment in this sector: hired labor on large farms and family labor on smallholdings. About employment, research findings in the field of "Social, Environmental and Economic Performance of 
Cotton" indicate that there will be a continuum from 'formality' to 'informality' in employment. Be that as it may, there is an increase in employment in cotton and related sectors.

India is no exception as the negative social impact of cotton plantations become more prominent, leading to an increase in suicides amongst farmers. In India, these farmers are mainly from the states of Andhra Pradesh and Punjab. The states of Karnataka, Maharashtra, and Gujarat also face this problem, though in a much smaller degree (Rao, 2004). These farmers often belong to the workforce age group and are dryland cultivators. It has been established that the main cause for these suicides is crop failure and heavy indebtedness, although social and psychological factors also contribute to such actions. Compared to the year 2010, cotton procurement prices have doubled, motivating a large number of farmers to enter the cotton cultivation, anticipating comparatively high profits. However, the rise in the price of fertilisers, power, diesel, the rental value of land, the cost of labor, and interest rates; combined with a failure of chemical control, a popularisation of hybrids, and a depleting of groundwater, have increased cotton cultivation costs remarkably.

In parallel, the change from GATT to WTO affected cotton plantation on the social front. The changed trading scenario caused price uncertainty, which further increased due to trade liberalisation. These developments unnerved the cotton planters, as some of them shifted from cotton to other cash crops. The rise in cost induced by domestic liberalisation, a decline in absolute productivity, and a credit squeeze caused a crisis of which the cotton planters became the victims. The situation was overcome through a new Indian policy framework that promoted liberalisation of tenancy laws, comprehensive insurance to cover price risk, an increase in research efforts, and the adoption of Integrated Pest Management measures by stepping up extension efforts and organic farming. ${ }^{8}$

\footnotetext{
8 Departement of Agriculture Cooperation and Farmers Welfare, 'Annual Report 2017-2018' (agricoop.nic.in, 2018) <http://agricoop.nic.in/sites/default/files/Krishi AR 2017-18-1 for web.pdf> accessed 28 March 2018.
} 
In India, cotton is often grown in small farms, employing the farmer and his family. Recently, the Government of India, through the Ministry of Agriculture, announced a mission "Doubling of Farmers' Income" (DFI), which also includes the cotton farmers. The DFI Mission is supposed to be achieved by India's 75th year of independence in 2022. In addition, there are other well-thought schemes for the social upliftment of farmers, these include crop insurance for mitigating losses (Pradhan Mantri Fasal Bima Yojana), soil improvement through the promotion of organic farming (Paramparagat Krishi Vikas Yojana), effective marketing through a unified national agricultural marketing platform (e-National Agricultural Market) and a GST rollout. These programs and plans will contribute to maximizing the gains from farming and improving the lives of cotton planters. As cotton planters often employ their children in farming, child labor remains a problem in cotton farms. This problem includes two types of child labor: underage seasonal workers hired for harvesting and forced child workers.

In some cases, children are forced to work in hazardous conditions, including the handling and application of pesticides and the use of unsafe machinery. The effect of pesticides on children is disproportionately high. Children absorb pesticides faster than adults; they have a lesser capability to detoxify and excrete toxic substances and thus, are at greater risk for chronic and long-term adverse health effects. Pesticides especially have a very harmful effect on the reproductive systems of pubescent girls.

\section{Conclusion}

Although India is the second top cotton producer of the world, with appropriate environmental and social laws, in terms of productivity, it is still far behind. Further, importers in developed countries have started asking for eco-labeling across the textile value chain. This requires a shift towards organic farming in the cotton plantation. Keeping in mind the definition of sustainability given by the ICAC in 2006, as 'the ability to produce cotton today without diminishing the ability of future generations to produce cotton'; one wonders how the cotton plantation in India can become sustainable without an efficient implementation of the provisions of law applicable to cotton plantation and a proper pricing of the produce. 


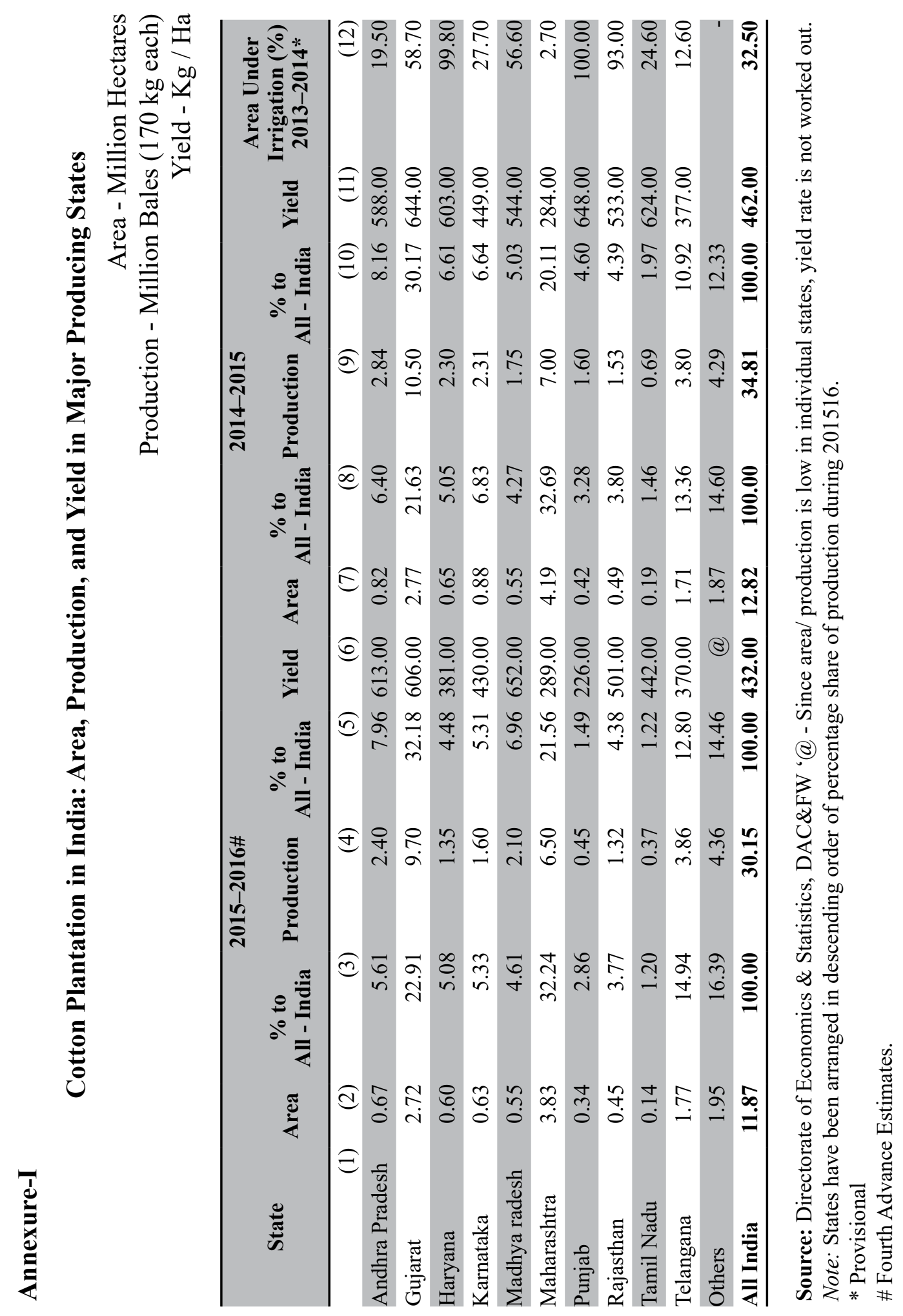




\section{Bibliography}

CITI, 'CITI CDRA' (Citi India, 2017) <https://www.citiindia.com/citi-cdra/> accessed 27 March 2018.

Cotton Advisory Board (P)*Provisional, 'CCI-An Organisation' (cotcorp.org.in, 2018) <https://cotcorp.org.in/Writereaddata/Downloads/FINAL CCI- An Organization.pdf $>$ accessed 23 March 2018.

Departement of Agriculture Cooperation and Farmers Welfare, 'Annual Report 2017-2018' (agricoop.nic.in, 2018) <http://agricoop.nic.in/sites/default/files/ Krishi AR 2017-18-1 for web.pdf $>$ accessed 28 March 2018.

Director and Member Secretary (TMC-MM-I) Central Institute for Cotton Research, 'Mission to Generate Technologies for Sustainable Cotton Production' (Technology Mission on Cotton, 2017) <http://www.tmc.cicr.org. in/> accessed 27 March 2018.

International Trade Centre, 'Cotton Exporter's Guide' (cottonguide, 2018) <http:// www.cottonguide.org/cotton-guide/market-segments-types-of-cotton/> accessed 23 March 2018.

Khushboo Sheth, 'Top Cotton Producing Countries in The World' (Worldatlas, $2017)<$ https://www.worldatlas.com/articles/top-cotton-producing-countriesin-the-world.html $>$ accessed 23 March 2018.

Textile Fashion Study, 'Cotton Cultivation: Top Cotton Producing Countries of the World' (Textile Fashion Study, 2013) < http://textilefashionstudy.com/ cotton-cultivation-top-cotton-producing-countries-of-the-world/ $>$ accessed 26 March 2018.

United States Department of Agriculture, 'Cotton Yield By Country in KG/HA' (United States Department of Agriculture, 2019) <https://www.indexmundi. com/agriculture/?commodity $=$ cotton $\&$ graph=yield $>$ accessed 26 March 2018. 